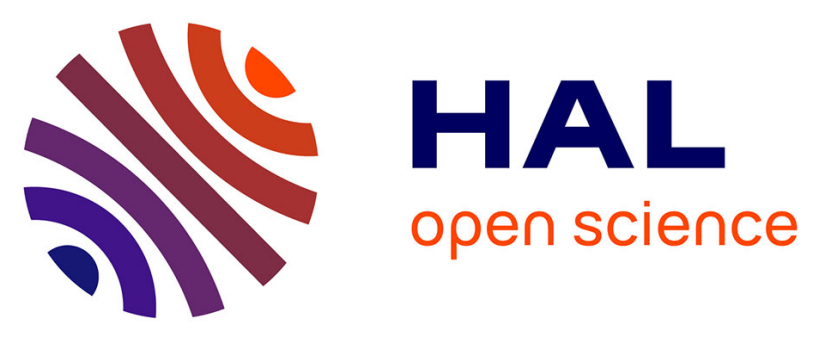

\title{
Characterization of gaseous odorous emissions from a rendering plant by GC/MS and treatment by biofiltration.
}

Benoît Anet, Marguerite Lemasle, Catherine Couriol, Thomas Lendormi, Abdeltif Amrane, Pierre Le Cloirec, Gilles Cogny, Romain Fillières

\section{To cite this version:}

Benoît Anet, Marguerite Lemasle, Catherine Couriol, Thomas Lendormi, Abdeltif Amrane, et al.. Characterization of gaseous odorous emissions from a rendering plant by GC/MS and treatment by biofiltration.. Journal of Environmental Management, 2013, 128, pp.981-7. 10.1016/j.jenvman.2013.06.028 . hal-00860108

\section{HAL Id: hal-00860108}

https://hal-univ-rennes1.archives-ouvertes.fr/hal-00860108

Submitted on 10 Oct 2013

HAL is a multi-disciplinary open access archive for the deposit and dissemination of scientific research documents, whether they are published or not. The documents may come from teaching and research institutions in France or abroad, or from public or private research centers.
L'archive ouverte pluridisciplinaire HAL, est destinée au dépôt et à la diffusion de documents scientifiques de niveau recherche, publiés ou non, émanant des établissements d'enseignement et de recherche français ou étrangers, des laboratoires publics ou privés. 


\title{
Characterization of gaseous odorous emissions from a rendering plant by GC/MS and treatment by biofiltration
}

\begin{abstract}
Benoît Anet ${ }^{\mathrm{a}, \mathrm{b}^{*}}$, Marguerite Lemasle ${ }^{\mathrm{b}}$, Catherine Couriole, Thomas Lendormi $^{\mathrm{e}}$, Abdeltif Amrane ${ }^{\mathrm{b}, \mathrm{e}}$, Pierre Le Cloirec ${ }^{\mathrm{b}, \mathrm{e}}$, Gilles Cogny ${ }^{\mathrm{a}}$, Romain Fillières ${ }^{d}$,
\end{abstract}

${ }^{a}$ Atemax France, Route d'Alençon, 61400 Saint-Langis-lès-Mortagne, France ${ }^{\text {b} E c o l e ~ N a t i o n a l e ~ S u p e ́ r i e u r e ~ d e ~ C h i m i e ~ d e ~ R e n n e s, ~ C N R S, ~ U M R ~ 6226, ~ A v e n u e ~}$ du général Leclerc, CS 50837, 35708 Rennes Cedex 7, France

'Laboratoire d'Ingénierie des Matériaux de Bretagne, EA 4250, Université de Bretagne Sud, Allée des Pommiers, 56300 Pontivy, France

${ }^{\mathrm{d} A k i o l i s ~ G r o u p,} 72$ Avenue Olivier Messiaen, 72000 Le Mans, France

eUniversité européenne de Bretagne

† Université Rennes1, UMR 6226, IUT, 3 Rue du Clos Courtel, 35704 Rennes Cedex 7, France

${ }^{*}$ Corresponding author. Tel:+33 6654404 55; Fax : + 33233254884.

E-mail address: benoit.anet@atemax.fr (B. Anet) 


\section{Abstract}

This research focus on the identification and quantification of odorous components in rendering plant emissions by GC/MS and other analytical methods, as well as the description of phenomena occurring in biofilter in order to improve the removal efficiency of industrial biofilters.

Among the 36 compounds quantified in the process air stream, methanethiol, isopentanal and hydrogen sulfide, presented the major odorous contributions according to their high concentrations, generally higher than 10 $\mathrm{mg} \cdot \mathrm{m}^{-3}$, and their low odorous detection thresholds. The elimination of such component mixtures by biofiltration (Peat packing material, EBRT: $113 \mathrm{~s}$ ) was investigated and revealed that more than $83 \%$ of hydrogen sulfide and isopentanal were removed by biofilter. Nevertheless, the incomplete degradation of such easily degradable pollutants suggested inappropriate conditions as lack of nutrients and acidic $\mathrm{pH}$. These inadequate conditions could explain the lack of performance, especially observed on methanethiol (53\% of RE) and the production of oxygenated and sulfur by-products by the biofilter itself.

Keywords: Rendering industry, Odorous emissions, Biofiltration, Odor analysis.

\section{Introduction}

Odors emitted by the rendering of animal by-products are among the most intense and less tolerated by surrounding neighbours (ADEME, 2008; Bourcier, 2005; Moletta, 2002). The discontent of the nearby population often leads to the 
emergence of protest groups and numerous local residents complaints. In order to warrant the welfare of the population and appease the social and political context within which rendering companies evolves, the control of these odours is of major importance.

Odorous emissions in a rendering plant are mainly due to the degradation and fermentation of the animal waste and by-products in the reception bins and the thermal degradation and drying during the rendering process. The heating of such animal tissues in cookers promotes degradation reactions (Maillard and Strecker reactions) and releases numerous odorous compounds (ADEME, 2008; Luo and Agnew, 2001; Luo and Lindsey, 2006; Rappert and Müller, 2005), such as sulfur (hydrogen sulfide, mercaptans and sulfides), nitrogenous (ammonia and amines), and oxygenated molecules (acids, ketones and aldehydes) (Kastner and Das, 2005; Rappert and Müller, 2005). These emissions contain numerous compounds at different levels of concentration depending on the type, quantity and freshness of the raw material processed, the type of process used and the period of the year (Luo and Agnew, 2001; Luo and Lindsey, 2006; Rappert and Müller, 2005). For example, 300 compounds were observed in the emissions of a rendering plant (Luo and Agnew, 2001; Luo and Van Oostrom, 1997). The odor concentration of the encountered flow is generally between 20,000 and 1,100,000 OU.m ${ }^{-3}$ (Luo and Lindsey, 2006; Luo and Van Oostrom, 1997; Shareefdeen et al., 2005; Sironi et al., 2007).

Preventive measures concerning the storage of raw materials and the application of strict cleaning rules are recommended to limit the production of odors (Bourcier, 2005; ITERG, 2001; Shareefdeen et al., 2005). However, the 
impact of such measures is often limited and leads inevitably to the implementation of air treatment units, where high purification efficiency is required to limit local residents complaints (Luo and Lindsey, 2006). Several processes such as thermal oxidation, chemical scrubbing and bioprocesses like biofiltration and bio-scrubbers have proven to be adapted (Bourcier, 2005; Kastner and Das, 2005; Luo and Lindsey, 2006; Sironi et al., 2007).

Biofiltration is one of the most used because its implementation remains easy at low investment and operating costs (Andres et al., 2006; Le Cloirec et al., 2001). The exhaust air stream is forced through a humidified packing material (peat, compost...) colonized by microorganisms which carry on the degradation of the odorous components into water, $\mathrm{CO}_{2}$, biomass, energy and metabolites (Le Cloirec et al., 2003; Mudliar et al., 2010).

The main aim of this research is to identify and quantify the chemical compounds responsible for the olfactory impact of rendering plants. In fact, previous work had focused on the characterisation of the composition of such rendering emissions but not deeply in the quantification of these pollutants. As a consequence a chemical characterization of the odorous air before and after the biofilter according to GC/MS and other analytical methods was done. The biofilter performances over each pollutant are presented and discussed in order to present the various adverse phenomena that can be observed on an industrial scale, but also to propose possible improvements. 


\section{Materials and methods}

\subsection{Rendering plant and biofilter configuration}

The rendering plant studied processes circa 175,000 tons per year of animal waste and by-products also called Specific Risk Materials (SRM) and operated continuously during 120 hours over the week. After grinding to a particle size of $30 \mathrm{~mm}$, the raw materials were dehydrated in continuous steam heated cookers at $130^{\circ} \mathrm{C}$ under 3 bars during 20 min. The evaporated steams emitted were continuously extracted and condensed by air condensers and water was sent to a wastewater treatment plant and the non-condensable fraction fed the air treatment process. The dehydrated material was pressed to remove grease from animal meal. The process air captured on these equipments were mixed to the ambient air of the facility and then oriented to the deodorization devices. A summary diagram of plant operations is described in Figure 1.

[Figure 1 close to here]

The deodorization process treat about $40,000 \mathrm{~m}^{3} \cdot \mathrm{h}^{-1}$ of a mixture of noncondensable gases emanating from three cookers and process gases pickedup on one fat press. The gas was first treated in an acid scrubber $(\mathrm{pH} \mathrm{4,}$ maintained by sulfuric acid injection and regulation, gas residence time: $1.3 \mathrm{~s}$ ) in order to remove nitrogenous compounds (ammonia and amines) and bring the relative humidity of the gas close to the saturation, upper than $98 \%$. The biofilter influent enters in the gas distribution system which consisted of a $70 \mathrm{~cm}$ plenum supporting a $20 \mathrm{~cm}$ layer of wood chips. The counter-current flow biofilter had a surface of $1050 \mathrm{~m}^{2}$ and a depth of $1.5 \mathrm{~m}$ (Empty Bed Residence Time (EBRT): 
113 s). It was filled with a mixture of peat and heather (volume percentage: $30 / 70$ ) on the first meter and covered with $30 \mathrm{~cm}$ of fibrous peat. The characteristics of these two materials, determined according to standards methods (Anet et al., 2012; Dorado et al., 2010) are summarized in Table 1. The biofilter was watered with the lagoon water from the wastewater treatment plant (WWTP), which presented the mean following composition on the period studied: $\left[\mathrm{N}-\mathrm{NH}_{4}{ }^{+}\right]: 0.85 \mathrm{mg} \cdot \mathrm{L}^{-1} ;\left[\mathrm{N}-\mathrm{NO}_{3}{ }^{-}\right]: 6.6 \mathrm{mg} \cdot \mathrm{L}^{-1} ;\left[\mathrm{P}^{-} \mathrm{PO}_{4}{ }^{3}\right]: 0.58 \mathrm{mg} \cdot \mathrm{L}^{-1} ; \mathrm{pH}:$ 8.0). There was no either nutrients supply on the operating period and no $\mathrm{pH}$ buffer incorporation at the biofilter start-up.

The industrial biofilter was covered and the outlet air stream was drawn at a flow rate of $80,000 \mathrm{~m}^{3} \cdot \mathrm{h}^{-1}$ and channeled before being released to the atmosphere by a chimney (of $30 \mathrm{~m}$ height). The gas sampling of the biofilter inlet and outlet was carried on the influent and effluents pipes according to methods described in the following paragraphs.

[Table 1 close to here]

\subsection{Gas sampling and analyses}

Gas samples were collected in accord to the AFNOR NF EN 13725 (CEN, 2003) sampling method with a box-lung system avoiding any contact between the $10 \mathrm{~L}$ - Nalophan ${ }^{\circledR}$ bag (Charles Frères, France fitted with a $8 \mathrm{~mm}$ Teflon tube, sealed by a Legris $\circledast$ stopper) and the pumping system.

The analysis of industrial emissions by gas chromatography coupled to mass spectrometry was used to quantify the compounds concentrations and to compare the odor thresholds. A suitable volume of $0.2 \mathrm{~L}$ for biofilter influent and $1 \mathrm{~L}$ for biofilter outlet was concentrated on Carbotrap 349 (Supelco®), with the 
a Gillian LFS-113 pump under a flow rate of $50 \mathrm{~mL} \cdot \mathrm{min}^{-1}$. The Carbotrap composition allows the selective retention of the heavy compounds from $\mathrm{C} 12$ to C20 on "Carbopack Y", while the "Carbopack B" trap the intermediate compounds C5 to C12, and the Carboxen 1003 adsorbs light compounds, from C2 to C5. The concentrates compounds are then thermally desorbed by a 400 Turbomatrix - Perkin Elmer $\AA$ unit and are oriented through a transfer line to the chromatographic column. The analytical conditions are described in Table 2.

[Table 2 close to here]

The Full Scan acquisition was used to analyze fragments ranging from 20 and $300 \mathrm{AMU}$ (Atomic Mass Unit). The compounds were identified by the comparison of obtained spectra with those referenced in the library of the "National Institute of Standards and Technology" (NIST) and quantified by external calibration developed in the ENSCR on the major odorous contributors. The detection limits for aldehydes, ketones, acids and alcohols were respectively $1.7,0.5,0.7$ and $0.3 \mu \mathrm{g} . \mathrm{m}^{-3}$ for the biofilter inlets and $0.33,0.10$, 0.14 and $0.07 \mu \mathrm{g} \cdot \mathrm{m}^{-3}$ for the biofilter outlets according to the sample volume concentrated on the adsorption tubes.

As mass spectroscopy remains unfitted to diluted air stream, a previous preconcentration step on concentrating cartridges is needed. This step could nevertheless affect the composition of the mixture, and thus the analytical results, as mercaptans could dimerize on activated carbon (Boulinguiez and Le Cloirec, 2010). Moreover, GC/MS is not adapted to the hydrogen sulfide detection and quantification as the mass spectrum of $\mathrm{H}_{2} \mathrm{~S}$ does not present any specific peaks. Therefore, the sulfur compounds concentrations were measured 
by a TRS MEDOR® analyzer (Chromatotec, France). The $400 \mu \mathrm{L}$ sample loop was continuously swept by the sample under a $100 \mathrm{~mL} \cdot \mathrm{min}^{-1}$ flow rate. The separation was performed on a capillary column swept by reconstituted air under 230 mbar, followed by an electrochemical detection in a cell filled with $\mathrm{CrO}_{3}$ at $10 \mathrm{~g} \cdot \mathrm{L}^{-1}$. The retention times were $70,110,170$ and $290 \mathrm{~s}$ respectively for dimethyldisulfide (DMDS), hydrogen sulfide $\left(\mathrm{H}_{2} \mathrm{~S}\right)$, methanethiol (MT) and ethanethiol $(E T)$. The external calibration was managed with a sulfur mixture of 20 ppm ( $\pm 2 p p m)$ for each components supplied by Linde Gas (Germany). The detection limits ranged between 35 and $45 \mu \mathrm{g} \cdot \mathrm{m}^{-3}$ for $\mathrm{H}_{2} \mathrm{~S}$, MT, ET and DMDS and is close to $75 \mu \mathrm{g} \cdot \mathrm{m}^{-3}$ for DMS.

\subsection{Packing material collection and analysis}

Packing material samples were collected at 30 and $70 \mathrm{~cm}$ bed height from the bottom each $117 \mathrm{~m}^{2}$ according to a regular squared grid collection plan. The sampling was carried on with an electric core drill (Dewalt $\circledast$ D21583K) fitted with a modified bit ( $\mathrm{L}: 400 \mathrm{~mm}, 102 \mathrm{~mm}$ ), to collect the sample without structural alteration. Humidity was determined by standard procedures. The $\mathrm{pH}$ of the packing material was measured with a Cyberscan ${ }^{\circledR} 510 \mathrm{pH}$-meter on leachates, after immerging and stirring $\left(1 \mathrm{~h}, 750 \mathrm{rpm}, 20^{\circ} \mathrm{C}\right) 4 \mathrm{~g}$ in $100 \mathrm{~mL}$ of ultra pure water. Sulfates and nitrates concentrations on the packing material were measured by ionic liquid chromatography equipped with a Dionex® AS50 autosampler and controlled by the Vistachrom® software (Dionex DX 120, Column: Dionex Ion Pac $\AA$ AS19. 4x250 mm; Pre-column: Dionex lon Pac ${ }^{\circledR}$ AG19. $4 \times 50 \mathrm{~mm}$, Injection volume: $500 \mu \mathrm{L}$, Eluent: $\mathrm{KOH}, 138$ bar at $1 \mathrm{~mL} \cdot \mathrm{min}^{-1}$, 
Concentration ramp of $2.33 \mathrm{~mm} \cdot \mathrm{min}^{-1}$ from 10 to $45 \mathrm{mM}$ after $10 \mathrm{~min}$ of equilibration time).

\section{Results and discussion}

\subsection{Influent biofilter gas composition}

The detailed composition of the biofilter influent is presented in Table 3. The results confirms the complexity of the rendering gaseous emissions, as previously reported (Luo and Agnew, 2001; Rappert and Müller, 2005). At the biofilter inlet, 36 compounds were observed and the most represented chemical families are: aldehydes (12), volatile fatty acids (7), alcohols (7), ketones (5) and sulfur compounds (5). Luo et al. (2001) had previously identified 55 volatile compounds among the 300 detected. The low number of components identified and quantified in this study is due to a deliberate restriction to the most odorous compounds family. Moreover, since the $\mathrm{pH}$ in the scrubber was maintained at 4 , basic compounds, such as ammonia and amines were not observed in the biofilter inlet. Among the identified compounds, the most concentrated pollutants at the biofilter inlet were $\mathrm{H}_{2} \mathrm{~S}, \mathrm{MT}$, isopentanal, isobutanal and ethanal with concentrations generally above $10 \mathrm{mg} \cdot \mathrm{m}^{-3}$.

[Table 3 close to here]

The odor intensity of a complex mixture cannot be predicted by a model integrating the concentrations of different chemical compounds (Rognon and Pourtier, 2000). However, in order to identify the compounds that could present the most odorous impact, it was suggested to calculate the odor activity value (OAV) of each quantified compound (Rappert and Müller, 2005). Neglecting 
inhibition or exaltation phenomena which certainly occurs, a theoretical odorous contribution can be calculated from the concentration and the odor threshold of a given compound, according to Devos et al. (1990) (Equation 1).

$$
\mathbf{O A V}=C_{G, i} / S_{p, i}
$$

With,

OAV : odor activity value of the compound $\mathrm{i}\left(\mathrm{OU} \cdot \mathrm{m}^{-3}\right)$;

$C_{G, i}:$ the concentration of the compound $\mathrm{i}\left(\mu \mathrm{g} \cdot \mathrm{m}^{-3}\right)$;

$S_{p, i}:$ the odor threshold of the compound $\mathrm{i}\left(\mu \mathrm{g} \cdot \mathrm{m}^{-3}\right)$ equivalent to one OU. $\mathrm{m}^{-3}$

The OAV chemical family, resulting from the sum of the contribution of each compound belonging to a given family, is presented in Figure 2. As observed, the reduced sulfur compounds and aldehydes contributed mostly to the odorous impact of rendering emissions. It is therefore required to focus efforts on the removal of these compounds. The detailed theoretical olfactory contribution of sulfur compounds, aldehydes and ketones are presented in Figure 3.

[Figure 2 close to here]

[Figure 3 close to here]

Among the quantified sulfur compounds, MT and $\mathrm{H}_{2} \mathrm{~S}$ were the main contributors. OAV are between 5700 and 9200 for the MT and between 545 and 677 for the $\mathrm{H}_{2} \mathrm{~S}$. Ethanethiol, observed only once, contributed to a lesser extent with an OAV close to 153. The OAV observed for DMS and DMDS, which remained below 54 and 16 respectively, were therefore not significant. 
Concerning aldehydes, isopentanal was the main contributor (OAV: 1459 3470).Isobutanal (26 to 124), ethanal ( 8 to 30 ) and, to a lesser extent, methacroleine (1 to 37 ) contributions appeared also significant. Hexanal, benzaldehyde and pentanal showed minor contributions with OAV less than 8 .

For the acids, butyric acid was found to be the most significant contributor with OAV between 19 and 133, followed by isopentanoic acid (26-106) and pentanoic acid (6-42). The OAV for propanoic, isobutyric, ethanoic and hexanoic acids were between 1 and 13, and hence can be considered as almost insignificant.

The olfactory ketones impact was mainly due to the presence of butadione showing odorous contributions between 27 and 168. The contribution of 2,3pentanedione remained unknown since no odor threshold was found for this compound. The OAV of acetone, methylethylketone (MEK), and methylisobutylketone (MIBK) appeared negligible and remained below 0.1.

According to these results, the mainly odorous contributors in rendering emissions were methanethiol and isopentanal, and to a lesser extent: $\mathrm{H}_{2} \mathrm{~S}$, isobutanal, butadione and the butyric and isopentanoic acids. The treatment of these pollutants needs to be efficient in order to reduce the olfactory impact of rendering plant.

\section{2. $\quad$ Biofilter characteristics and performances}

The biofilter chemical properties are reported in Table 4. This result suggests that the humidity of the packing material remained stable during all the study, and close to recommended values of $60-70 \%$ for peat and heather biofilter. Nevertheless, the $\mathrm{pH}$ of the packing material was acidic, especially in 
the first stratum, and tended to decline with time according to the sulfuric acid accumulation along the operation period.

The biofilter removal efficiencies reported in Table 3 are higher than $83 \%$ for aldehydes and $63 \%$ for ketones. The removal capacities $\left(\mathrm{mg} \cdot \mathrm{m}^{-3} \cdot \mathrm{h}^{-1}\right)$ ranged from a few mg to a few hundred mg for the treatment of ethanal, isopentanal, methacroleine and isobutanal.

Regarding the elimination of sulfur compounds, the biofilter showed good elimination of $\mathrm{H}_{2} \mathrm{~S}$, with removal efficiency in the range of 84 to $90 \%$. Lower performances were observed on the reduction of MT and DMS, with removal efficiencies respectively in the range of 50 to $74 \%$ and 35 to $77 \%$. The lower performances concerning these compounds were in line with previous studies (Legrand, 2011; Myung Cha et al., 1999; Soupramanien et al., 2012), showing that MT and DMS elimination was more difficult in comparison to $\mathrm{H}_{2} \mathrm{~S}$. Such differences could be attributed firstly to an inhibition of the DMS and methanethiol degradation by $\mathrm{H}_{2} \mathrm{~S}$, associated to the energy liberated during the pollutant degradation, were the oxidation of $\mathrm{H}_{2} \mathrm{~S}$ bring more energy to microorganisms in comparison with the energy liberated by MT and DMDS (Smet et al., 1998).

Moreover the sulfuric acid production during the $\mathrm{H}_{2} \mathrm{~S}$ biodegradation (Anet et al., 2012; Dumont et al., 2008) can inhibits the degradation of others reduced sulfur compounds. For example, the DMS biodegradation which was strongly inhibited below pH= 5 (Sercu et al., 2005; Soupramanien et al., 2012).

The performances towards DMDS suggested the production of this compound by the biofilter itself. It was already reported (van Leerdam et al., 
2008) that this compound could be produced by chemical oxidation of MT in aerobic conditions $\left(2 \mathrm{CH}_{3} \mathrm{SH}+1 / 2 \mathrm{O}_{2} \rightarrow \mathrm{CH}_{3}-\mathrm{S}-\mathrm{SCH}_{3}+\mathrm{H}_{2} \mathrm{O}\right)$. It seems that, in this biofilter, the physical and chemical characteristics of the biofilm seem to favour this chemical reaction. Moreover MT can also react with biosulfur particles, leading to the formation of dimethylpolysulfide $\left(\left(\mathrm{CH}_{3}\right)_{2} \mathrm{~S}_{2}\right.$ and $\left.\left.\left(\mathrm{CH}_{3}\right)_{2} \mathrm{~S}_{3}\right)\right)$ (van Leerdam et al., 2011).

The degradation of alcohols was also investigated even though they did not have an odorous impact at the biofilter inlet. The elimination of simple linear alcohols such as methanol, ethanol and propanol remained efficient with removal efficiencies higher than $79 \%$. Performances on isobutanol, pentanol and volatile acids were also limited and even negative suggesting a production during the biofiltration step. These phenomena were previously reported by several authors. During the degradation of ethyl acetate, Deshusses et al. (1999, a) observed the production of ethanol and other unidentified compounds by the biofilter. When treating high loads of isobutanal, Sercu et al. (2005) observed a rapid exhaustion of nutrients, leading to a partial degradation and the formation of by-products, such as isobutanol and isobutyric acid. They also noted an increase of isobutanol production at acidic $\mathrm{pH}(\mathrm{pH}=5.2)$, compared to an alkaline medium $(\mathrm{pH}=8.4)$, and have related this phenomenon to the slower degradation kinetics of isobutanol under acidic conditions.

The biofilter performances on isopentanal, $\mathrm{H}_{2} \mathrm{~S}$ and $\mathrm{MT}$ are reported in Figure 4, which reports a good correlation between the treated loads as a function of the inlet loads applied. As reported in Table 3, the highest removal efficiency is observed for isopentanal and $\mathrm{H}_{2} \mathrm{~S}$. Nevertheless, incomplete 
elimination was observed even if the load applied remained low. For example, $26 \mathrm{~s}$ is sufficient to remove successfully loads up to $4.5 \mathrm{~g} \mathrm{H}_{2} \mathrm{~S} \cdot \mathrm{m}^{-3} \cdot \mathrm{h}^{-1}$ (RE higher than $96 \%$ ) on pines barks biofilter (Gaudin et al., 2008). Moreover, Kastner et al. (2005) observed a total elimination of isopentanal on mulch and bark biofilter up to an inlet load of $3 \mathrm{~g} \cdot \mathrm{m}^{-3} \cdot \mathrm{h}^{-1}$ for isopentanal.

From these observations, four hypotheses can be formulated to explain the formation of alcohol and acid by-products in this study. First, the treatment of high loads of isopentanal and isobutanal leads to a partial degradation and to the formation of by-products which are not totally removed by the biofilter.

Secondly, despite a favourable high gas residence time (EBRT: 113 s), the degradation kinetics seem to be inhibited by unfavourable operating conditions like acidic $\mathrm{pH}$ along the biofilter height. Sulfuric acid production during hydrogen $\mathrm{H}_{2} \mathrm{~S}$ degradation, inhibits most probably the microbial activity and as a consequence the removal efficiency over recalcitrant pollutants.

Moreover, the nutrient balance applied to the biofilter was extremely low as the $\mathrm{C} / \mathrm{N} / \mathrm{P}$ ratio was equal to $100 / 0.6 / 0.04$. As a consequence this system suffers from nutrients lack which can reduce the microbial activity. Even though the use of nutrient solutions was not current at an industrial scale for economical and practical reasons (clogging of the pumping and dispersion system), the incorporation of nutrients in a solid form should be considered for stimulating the growth and microbial activity.

Finally, the incomplete elimination of isopentanal and hydrogen sulphide, at low inlet load (>0.7 gisopentanal. $\mathrm{m}^{-3} \cdot \mathrm{h}^{-1}$ and $\left.>0.5 \mathrm{~g} \mathrm{H}_{2} \mathrm{~S} \cdot \mathrm{m}^{-3} \cdot \mathrm{h}^{-1}\right)$ suggests the existence of preferential flow paths in the packing, as previously reported on 
this packing material (Anet et al., 2012), where the performances are reduced. So the selection of a more appropriate media according to a hydrodynamical point of view would reduce these phenomena.

3.3. Theoretical odorous contribution of pollutants at biofilter outlet

The detailed theoretical olfactory contribution of each compound at the biofilter outlet is presented in Figure 5. Only few components showed major odorous contributions. According to the performances observed, the MT presented the most important odorous impact with OAV between 2175 and 4553, far above the other sulfur compounds such as $\mathrm{H}_{2} \mathrm{~S}$ (OAV from 70 to 88), DMS and DMDS (11 to 23). Even if isopentanal was satisfactorily treated, its contribution appeared non negligible with OAV ranging from 92 to 172 . The OAV of pentanoic, isopentanoic and butyric acids which are produced by the biofilter itself, ranged respectively from 2 to 98,10 to 183 and 8 to 203 .

[Figure 5 close to here]

\section{Conclusions}

This study showed that the gaseous emissions of a rendering site are composed of a complex mixture of chemical compounds. Among the 36 identified and quantified in the process air stream at the biofilter inlet, the most concentrated pollutants were hydrogen sulfide, methanethiol, isopentanal and isobutanal with concentrations generally above10 $\mathrm{mg} \cdot \mathrm{m}^{-3}$.Their theoretical odorous contributions were calculated based on their respective odor thresholds. This revealed, that after a chemical scrubbing at $\mathrm{pH}=4$ which removed the nitrogenous compounds (ammonia and amines) the most odorous contributors were methanethiol, isopentanal and hydrogen sulfide. 
The elimination of hydrogen sulfide, aldehydes and ketones was quite efficient with removal efficiencies respectively over $84 \%, 83 \%$ and $62 \%$.The concentration of methanethiol at the biofilter outlet remained high, according to the poor removal efficiency on this pollutant (close to 53\%) and could explain the residual odor emitted. The treatment of such compounds needs to be optimized in order to limit the olfactory nuisances of rendering plants. Finally, the formation of alcohols and acids by the biofilter underlines that the operating conditions applied were unfavourable, which underlined the need for $\mathrm{pH}$ correction and nutrients supply management. Moreover, the incomplete degradation of hydrogen sulfide, even at low inlet loads, suggests the existence of preferential flow paths in the packing material which underscore the importance of the selection of more structured materials.

\section{Acknowledgements}

The authors acknowledge the Atemax France company for the funding of this study. 
References

ADEME, 2008. Pollutions olfactives : origine, législation, analyse, traitement. Second ed. Ademe, Angers.

Andres, Y., Dumont, E., Le Cloirec, P., Ramirez-Lopez, E., 2006. Wood Bark as Packing Material in a Biofilter used for Air Treatment. Environmental Technology, 27, 1297-1301.

Anet, B., Couriol, C., Lendormi, T., Amrane, A., Le Cloirec, P., Cogny, G., Fillières, R., 2012. Characterization of gaseous effluent and packing material autopsy of a biofilter operating in the rendering industry. Internationnal Conference on Control of Industrial Gaseous Emissions. $9-10^{\text {th }}$ February 2012, Annamalai University, Chidambaram, India.

Anet, B., Couriol, C., Lendormi, T., Amrane, A., Le Cloirec, P., Cogny, G., Fillières, R., 2012. Packing Material Evolutions and Odorous Abatement of Peat and Heather Biofilters Operating in Rendering Industry. Chemical Engineering Transactions, 30, 61-66.

Boulinguiez, B., Le Cloirec, P., 2010. Chemical transformations of sulfur compounds adsorbed onto activated carbon materials during thermal desorption. Carbon, 48, 1558-1569.

Bourcier, J., 2005. Equarrissage: Traitement des émissions gazeuses. Les techniques de l'ingénieur, Traité environnement 1-12.

CEN, 2003. EN 13725 - Qualité de l'air-Détermination de la concentration d'une odeur par olfactométrie dynamique. CEN.

Deshusses, M., Johnson, C.T., Leson, G., 1999, a. Biofiltration of high loads of ethyl acetate in the presence of toluene. Journal of the Air \& Waste Management Association, 49, 973-979.

Devos, M., Patte, F., Rouault, J., Laffort, P., Van Gemert, L.J., 1990. Standardized human olfactory thresholds. Oxford University Press, New York.

Dorado, A., Lafuente, F., Gabriel, D., Gamisans, X., 2010. A comparative study based on physical characteristics of suitable packing materials in biofiltration. Environmental Technology, 31, 193-204.

Dumont, E., Andrès, Y., Le Cloirec, P., Gaudin, F., 2008. Evaluation of a new packing material for $\mathrm{H}_{2} \mathrm{~S}$ removed by biofiltration. Biochemical Engineering Journal, 42, 120-127.

Gaudin, F., Andres, Y., Le Cloirec, P., 2008. Packing material formulation for odorous emission biofiltration. Chemosphere, 70, 958-966.

ITERG, 2001. Caractérisation des odeurs émises par l'agro-industrie et détermination des traitements appropriés. ITERG, pp. 72.

Kastner, J.R., Das K. C., 2005. Comparison of chemical wet scrubbers and biofiltration for control of volatile organic compounds using GC/MS 
techniques and kinetic analysis. Journal of Chemical Technology \& Biotechnology 80(10), 1170-1179.

Le Cloirec, P., Fanlo, J.-L., Gracian, C., 2003. Traitement des odeurs : Procédés curatifs. Les techniques de l'ingénieur, Traité environnement 1-14.

Le Cloirec, P., Humeau, P., Ramirez-Lopez, E., 2001. Biotreatments of odours: control and performances of a biofilter and a bioscrubber. Water Science and Technology, 44, 219-226.

Legrand, P., 2011. Traitement de composés soufrés organiques récalcitrants par biofiltration : optimisation des conditions opératoires pour une application industrielle Université de Montpellier 2. Ecole des Mines d'Alès, Alès, pp. 195.

Luo, J., Agnew, M.P., 2001. Gas characteristics before and after biofiltration treating odorous emissions from animal rendering processes. Environmental Technology, 22, 1091-1103.

Luo, J., Lindsey, S., 2006. The use of pine bark and natural zeolite as biofilter media to remove animal rendering process odours. Bioresource Technology, 97, 1461-1469.

Luo, J., Van Oostrom, A.J., 1997. Biofilters for controlling animal rendering odour - a pilot scale study. Pure and Applied Chemistry, 69, 2403-2410.

Moletta, R., 2002. Gestion des problèmes environnementaux dans les industries agroalimentaires. Fisrt ed. Lavoisier, Paris.

Mudliar, S., Giri, B., Padoley, K., Satpute, D., Dixit, R., Bhatt, P., Pandey, R., Juwarkar, A., Vaidya, A., 2010. Bioreactors for treatment of VOCs and odours - A review. Journal of Environmental Management, 91, 1039-1054.

Myung Cha, J., Suk Cha, W., Lee, J., 1999. Removal of organo-sulphur odour compounds by Thiobacillus novellus SRM, sulphur-oxidizing microorganisms. Process Biochemistry, 34, 659-665.

Rappert, S., Müller, R., 2005. Microbial degradation of selected odorous substances. Waste Management, 25, 940-954.

Rappert, S., Müller, R., 2005. Odor compounds in waste gas emissions from agricultural operations and food industries. Waste Management, 25, 887-907.

Rognon, C., Pourtier, L., 2000. Les odeurs dans l'environnement. Les techniques de l'ingénieur, Traité environnement, 1-11.

Sercu, B., Demeestere, K., Baillieul, H., Van Langenhove, H., Verstraete, W., 2005. Degradation of isobutanal at high loading rates in a compost biofilter. Journal of the Air \& Waste Management Association, 55, 1217-1227.

Sercu, B., Núñez, D., Van Langenhove, H., Aroca, G., Verstraete, W., 2005. Operational and microbiological aspects of a bioaugmented two- 
stage biotrickling filter removing hydrogen sulfide and dimethyl sulfide. Biotechnology and bioengineering, 90, 259-269.

Shareefdeen, Z., Herner, B., Webb, D., Verhaeghe, L., Wilson, S., 2005. An odor predictive model for rendering applications. Chemical Engineering Journal, 113, 215-220.

Shareefdeen, Z., Singh, A., Popov, V., Zhukov, V., 2005. Odor Removal in Industrial Facilities Biotechnology for Odor and Air Pollution Control. Springer Berlin Heidelberg, pp. 305-326.

Sironi, S., Capelli, L., Céntola, P., Del Rosso, R., Grande, M.I., 2007. Odour emission factors for assessment and prediction of Italian rendering plants odour impact. Chemical Engineering Journal, 131, 225-231.

Smet, E., Lens, P., Van Langenhove, H., 1998. Treatment of waste gases contaminated with odorous sulfur compounds. Critical Reviews in Environmental Science and Technology, 28, 89-117.

Soupramanien, A., Malhautier, L., Dumont, E., Andrès, Y., Rocher, J., Fanlo, J.-L., 2012. Biological treatment of a mixture of gaseous sulphur reduced compounds: identification of the total bacterial community's structure. Journal of Chemical Technology \& Biotechnology, 87, 817-823.

van Leerdam, R.C., Bonilla-Salinas, M., de Bok, F.A., Bruning, H., Lens, P.N., Stams, A.J., Janssen, A.J., 2008. Anaerobic methanethiol degradation and methanogenic community analysis in an alkaline (pH 10) biological process for liquefied petroleum gas desulfurization. Biotechnology and bioengineering, 101, 691-701.

van Leerdam, R.C., van den Bosch, P.L.F., Lens, P.N.L., Janssen, A.J.H., 2011. Reactions between Methanethiol and Biologically Produced Sulfur Particles. Environmental Science \& Technology, 45, 13201326. 


\section{Figure and Table Captions}

Table 1 Physico-chemical and biological properties of the packing materials

Table 2 Analytical conditions of the GC/MS apparatus

Table 3 Concentrations and odor thresholds of chemical compounds observed at the biofilter inlet and biofilter performances

Table 4 Chemical properties evolutions of the packing the packing material

Figure 1 Schematic diagram of the industrial transformation process and the deodorization unit

Figure 2 Theoretical odorous contributions of the major compound families at the biofilter inlet $\left(\mathrm{OU}_{\text {theo }} \cdot \mathrm{m}^{-3}\right)$

Figure 3 Theoretical odorous contributions of the identified compounds at the biofilter inlet $\left(\mathrm{OU}_{\text {theo }} \cdot \mathrm{m}^{-3}\right)$

Figure 4 Performances of the biofilter on hydrogen sulfide, methanethiol and isopentanal as a function of the applied loads

Figure 5 Theoretical odorous contributions of the identified compounds at the biofilter outlet $\left(\mathrm{OU}_{\text {theo }} \cdot \mathrm{m}^{-3}\right)$ 
Table 1

\begin{tabular}{llll}
\hline Material & Fibrous peat & Heather & Peat and heather mixture \\
\hline $\mathrm{pH}$ & 4.22 & 5.66 & 4.31 \\
$\mathrm{M} . \mathrm{O}$. & $99.0 \%$ & $98.9 \%$ & $98.9 \%$ \\
$\% \mathrm{C}$ & $51.6 \%$ & $52.8 \%$ & $51.9 \%$ \\
$\% \mathrm{O}$ & $42.5 \%$ & $41.3 \%$ & $42.1 \%$ \\
$\% \mathrm{H}$ & $5.2 \%$ & $6.0 \%$ & $6.0 \%$ \\
$\% \mathrm{~N}$ & $0.7 \%$ & $0.6 \%$ & $0.6 \%$ \\
\hline$\varepsilon(-)$ & $61.5 \%$ & $78.8 \%$ & $74.4 \%$ \\
$\rho(\mathrm{kg} \cdot \mathrm{m}-3)$ & $/$ & $/$ & 25 \\
$C_{\mathrm{H}_{\mathbf{z}} O}\left(\mathrm{~g} \cdot \mathrm{g}^{-1}\right)$ & $/$ & $/$ & 2.3 \\
\hline Log $\left(\mathrm{ng} \mathrm{ATP} . \mathrm{m}^{-3}\right)$ & $/$ & $/$ & 6.7 \\
Log $\left(\mathrm{UFC} \cdot \mathrm{m}^{-3}\right)$ & $/$ & $/$ & 11.2 \\
\hline Cost $\left(€ . \mathrm{m}^{-3}\right)$ & $/$ & $/$ & 45 \\
\hline
\end{tabular}


Table 2

\begin{tabular}{ll}
\hline Parameters & Conditions \\
\hline Thermal desorption & $280^{\circ} \mathrm{C}$ under $\mathrm{N}_{2}\left(50 \mathrm{~mL} \cdot \mathrm{min}^{-1}\right)$ \\
Internal concentration & $5^{\circ} \mathrm{C}$ on "Carboxen $2003^{\prime \prime}$ and "Carbopack B" trap \\
Thermal desorption & $280^{\circ} \mathrm{C}$ under $1 \mathrm{~mL} \cdot \mathrm{min}^{-1}$ \\
Carrier gas & $\mathrm{He}$ at 3.1 bars \\
Column & $\mathrm{CP}-\mathrm{FFAP} \mathrm{CB}-25 \mathrm{~m} \times 0.15 \mathrm{~mm} \times 0.25 \mu \mathrm{m}$, Varian ${ }^{\circledR}$ \\
Temperature & $10^{\circ} \mathrm{C} \cdot \mathrm{min}^{-1}$ from 60 to $200^{\circ} \mathrm{C}$ after $5 \mathrm{~min}$ of equilibrium \\
lonization & Electronic impact \\
Detector & Quadrupole mass spectrometer Clarus 500 - Perkin Elmer ${ }^{\circledR}$ \\
\hline
\end{tabular}


Table 3

\begin{tabular}{|c|c|c|c|c|c|c|}
\hline \multirow[b]{3}{*}{ Gas Temp. $\left({ }^{\circ} \mathrm{C}\right)$} & \multicolumn{3}{|c|}{ Biofilter inlet $\left(\mu \mathrm{g} \cdot \mathrm{m}^{-3}\right)$} & \multirow{3}{*}{$\mathrm{RE}(\%)$} & \multirow{3}{*}{$\begin{array}{l}\text { Treated load } \\
\left(\mathrm{mg} \cdot \mathrm{m}^{-3} \cdot \mathrm{h}^{-1}\right)\end{array}$} & \multirow{3}{*}{$\begin{array}{c}S p \\
\left(\mu g \cdot m^{-3}\right)\end{array}$} \\
\hline & $01 / 2011$ & $03 / 2011$ & $04 / 2011$ & & & \\
\hline & 24.8 & 26.1 & 32.2 & & & \\
\hline Hydrogen sulfide & 17400 & 14000 & 15500 & $84-90 \%$ & 298 to 380 & 25.7 \\
\hline Dimethylsufide & 320 & 185 & 210 & 35 to $77 \%$ & 2 to 6 & 5.89 \\
\hline Dimethyldisulfide & 280 & 170 & 770 & -41 to $-219 \%$ & -8 to -20 & 47.9 \\
\hline Methanethiol & 17600 & 11900 & 19200 & 50 to $74 \%$ & 156 to 293 & 2.09 \\
\hline Ethanethiol & 430 & $\mathrm{Nd}$ & $\mathrm{Nd}$ & $100 \%$ & 11 & 2.82 \\
\hline Ethanal & 10228 & 4473 & 2882 & 99 to $100 \%$ & 73 to 259 & 342 \\
\hline Methacroleine & 14315 & 313 & 553 & 95 to $97 \%$ & 8 to 343 & 389 \\
\hline Butanal & $\mathrm{Nd}$ & 100 & 240 & 97 to $100 \%$ & 3 to 6 & 27.5 \\
\hline Isobutanal & 5947 & 3238 & 15304 & 84 to $97 \%$ & 69 to 375 & 123 \\
\hline Isopentanal & 25764 & 16046 & 11860 & 94 to $95 \%$ & 281 to 605 & 8.13 \\
\hline Pent-2-enal & 651 & 65 & 112 & 83 to $94 \%$ & 1 to 15 & - \\
\hline Pentanal & 209 & 152 & 138 & 91 to $100 \%$ & 3 to 5 & 25.1 \\
\hline 2-ethylbut-2-enal & $\mathrm{Nd}$ & 370 & $\mathrm{Nd}$ & $92 \%$ & 9 & - \\
\hline Crotonaldehyde & $\mathrm{Nd}$ & 24 & $\mathrm{Nd}$ & $100 \%$ & 1 & - \\
\hline Hexanal & 259 & 116 & 67 & 88 to $92 \%$ & 2 to 5 & 57.7 \\
\hline 2-methylbut-2-enal & 649 & 182 & 258 & 89 to $100 \%$ & 4 to 16 & - \\
\hline Benzaldehyde & 33 & 14 & 2 & -29 to $48 \%$ & 0 to 0,2 & 186 \\
\hline Acetone & 1853 & 692 & 1279 & 63 to $95 \%$ & 14 to 31 & 34700 \\
\hline MEK & 3417 & 549 & 566 & 80 to $93 \%$ & 11 to 78 & 23400 \\
\hline Butadione & 2661 & 481 & 426 & 93 to $96 \%$ & 10 to 64 & 15.8 \\
\hline MIBK & 7 & $\mathrm{Nd}$ & 2 & $100 \%$ & 0 & 2290 \\
\hline 2,3-pentanedione & 464 & 22 & 9 & 79 to $100 \%$ & 0,2 to 12 & - \\
\hline Ethanoic acid & 3118 & 152 & 137 & -46 to $-103 \%$ & -4 to -74 & 363 \\
\hline Propanoic acid & 1372 & 99 & 224 & -42 to $15 \%$ & -3 to 1 & 110 \\
\hline Isobutyric acid & 931 & 471 & 456 & -30 to $61 \%$ & -17 to 7 & 72.4 \\
\hline Butyric acid & 1923 & 275 & 273 & -56 to $60 \%$ & -52 to 4 & 14.5 \\
\hline Isopentanoic acid & 1110 & 275 & 275 & -73 to $59 \%$ & -36 to 4 & 10.5 \\
\hline Pentanoic acid & 852 & 127 & 132 & -135 to $66 \%$ & -46 to 2 & 20.4 \\
\hline Hexanoic acid & 510 & $\mathrm{Nd}$ & $\mathrm{Nd}$ & $-149 \%$ & -30 & 60.3 \\
\hline Methanol & 256 & 161 & 158 & 79 to $100 \%$ & 3 to 6 & 186000 \\
\hline Ethanol & 3106 & 1441 & 3252 & 84 to $98 \%$ & 36 to 81 & 55000 \\
\hline Propanol & 1263 & 10 & 57 & 85 to $96 \%$ & 0 to 26 & 6010 \\
\hline Butan-2-ol & $\mathrm{Nd}$ & 57 & $\mathrm{Nd}$ & $83 \%$ & 1 & 5250 \\
\hline Isobutanol & 17 & 203 & 7 & -43 to $-1168 \%$ & -7 to 50 & 2570 \\
\hline Butanol & 285 & $\mathrm{Nd}$ & 52 & 63 to $80 \%$ & 0 to 5 & 1510 \\
\hline Pentanol & 110 & 44 & 28 & -33 to $-340 \%$ & -13 to 0 & 1720 \\
\hline
\end{tabular}

Nd: Not detected

$\mathrm{Sp}$ : odor Threshold compilated by Devos et al. (Devos et al., 1990) 
Table 4

\begin{tabular}{llllll}
\hline Height & Date & $\mathrm{pH}$ & Humidity (\%) & {$\left[\mathrm{SO}_{4}{ }^{2-}\right]\left(\mathrm{mgS}_{\mathrm{kg}}{ }^{-1}\right)$} & {$\left[\mathrm{NO}_{3}{ }^{-}\right]\left(\mathrm{mgN}_{\mathrm{kg}}{ }^{-1}\right)$} \\
\hline \multirow{2}{*}{$30 \mathrm{~cm}$} & January 2011 & $2.4(0.8)$ & $62.3(16.8)$ & $7567(8503)$ & $31(50)$ \\
\cline { 2 - 6 } & March 2011 & $2.5(0.5)$ & $66.2(6.9)$ & $8927(9994)$ & $24(29)$ \\
\hline \multirow{2}{*}{$70 \mathrm{~cm}$} & January 2011 & $2.7(1.1)$ & $75.5(8.9)$ & $5481(6484)$ & $89(119)$ \\
\cline { 2 - 6 } & March 2011 & $3.4(1.6)$ & $75.8(3.0)$ & $5810(8668)$ & $79(99)$ \\
\hline
\end{tabular}

${ }^{*}$ Data reported are the average of the 9 samples collected at each period and bed height. Standard deviations are reported in brackets. 